\title{
PENGARUH MODEL PEMBELAJARAN PROBLEM BASED LEARNING TERHADAP HASIL BELAJAR MATEMATIKA SISWA KELAS VIII SMP NEGERI 48 SURABAYA
}

\author{
Indri Darlin ${ }^{1}$, Nur Fathonah ${ }^{2}$ \\ Prodi Pendidikan Matematika Universitas PGRI Adi Buana Surabaya ${ }^{1,2}$ \\ indriloguil@gmail.com ${ }^{1}$
}

\begin{abstract}
Abstrak
Yang melatar belakangi penelitian ini yaitu kesukaran yang sering dihadapi peserta didik untuk mendapatkan hasil belajar matematika yang memuaskan dikarenakan pembelajaran yang membosankan dan cenderung monoton, siswa malas berpikir dan tidak memperhatikan materi yang dijelaskan oleh pendidik sehingga berpengaruh terhadap hasil belajar. Hal tersebut dapat menjadi pandangan sebagai suatu kondisi yang memerlukan adanya inovasi baru dalam mengajar dengan menggunakan model pembelajaran. Model pembelajaran yang dapat melibatkan secara langsung siswa untuk lebih responsif, punya nalar tinggi, keuletan, perhatian dan motivasi. Supaya dapat memahami pembelajaran matematika. Penelitian ini merupakan jenis penelitian eksperimen dengan maksud agar mengetahui apakah ada pengaruh model pembelajaran problem posing terhadap hasil belajar matematika materi relasi dan fungsi siswa kelas VIII SMP Negeri 48 Surabaya. Dalam penelitian ini populasinya semua siswa kelas VIII SMPN 48 Surabaya. Teknik pengambilan sampel pada penelitian ini dengan rekomendasi guru pamong berdasarkan nilai rata-rata raport siswa. Ada dua kelas yang dipilih sebagai sampel yaitu kelas VIII-I sebagai kelas kontrol dan kelas VIII-J sebagai kelas eksperimen. Metode yang digunakan yaitu metode penelitian eksperimen dengan pendekatan kuantitatif. Teknik pengumpulan data menggunakan metode test yaitu lembar post-test dan dokumentasi. Adapun teknik analisis data menggunakan uji normalitas dan uji homogenitas sebagai syarat uji-t kesamaan dua rataan. Sesuaui hasil pengujian rata-rata post-test hasil belajar matematika siswa kelas eksperimen adalah 90,74 dan nilai rata-rata post-test kelas kontrol adalah 86,16 , terlihat bahwa nilai rata-rata kelas eksperimen lebih tinggi dari pada nilai rata-rata kelas kontrol. Sesuai dengan hipotesis nilai $t$ untuk kedua kelas yaitu thitung $=2,75$ dan $t_{\text {tabel }}=1,992$. Hasil ini berakibat, $t_{\text {hitung }}>t_{\text {tabel }}$ yaitu 2,75 $>1,992$, dapat disimpulkan bahwa hasil belajar matematika siswa dengan menggunakan model pembelajaran problem posing lebih tinggi dari pada hasil nilai matematika siswa dengan menggunakan model pembelajaran langsung.
\end{abstract}

Kata Kunci: model pembelajaran langsung, model pembelajaran problem posing, hasil belajar matematika 


\section{A. Pendahuluan}

Menurut perundang-undangan No.20 Tahun 2013 mengenai sistem pendidikan Nasional pasal 1 ayat 1 tertulis bahwa " sesungguhnya pendidikan adalah suatu usaha sadar dan terencana untuk mewujudkan suasana belajar dan proses belajar mengajar supaya siswa secara aktif mengelaborasi potensi dirinya untuk memiliki kekuatan spiritual keagamaan, kepribadian, kecerdasan, akhlak mulia, pengendalian diri, serta keterampilan yang diperlukan baik masyarakat, dirinya sendiri, maupun bangsa dan Negara".

Dari pengamatan diatas kita bisa mengartikan bahwasanya pendidikan sangat penting bagi setiap orang terutama peserta didik dan dilaksanakan dengan sadar untuk mempersiapkan siswa kedepannya dalam berlombah ataupun baradaptasi di era globalisasi. Akan tetapi hampir semua peserta didik berasumsi bahwasanya matematika adalah mata pelajaran yang sukar di mengerti. Dalam hal ini tidak diherankan karena matematika adalah pelajaran yang konsepnya hierarkis dari yang mudah atau sederhana sampai ke yang sulit. Berkaitan dengan hasil belajar peserta didik, Dimyati Mudjiono (2013 : 3) berpendapat bahwa “ Hasil dari suatu interaksi tindak belajar dan tindak mengajar merupakan hasil dari belajar itu sendiri. Evaluasi hasil belajar dilakukan untuk proses pembelajaran oleh pendidik. Untuk menjadi tolak ukur keberhasilan siswa serta berakhirnya puncak proses belajar dapat dilihat dari hasil belajar siswa pada materi pelajaran tertentu.

Kurikulum 2013 merupakan jawaban tentang beberapa permasalahan pendidikan matematika di Indonesia yaitu mengembangkan kemampuan siswa mulai dari pengamatan permasalahan konkret, kemudian ke semi konkret, dan akhirnya abtraksi permasalahan. Siswa menerima materi tentang rumus-rumus dan permasalahan-permasalahan dari guru, selanjutnya siswa diminta menerapkan atau menggunakan rumus-rumus tersebut untuk pemecahan permasalahan tersebut sesuai dengan materi tertentu. Membiasakan siswa berpikir algoritmis. Informasi lain yang diperoleh dari sekolah-sekolah adalah mengenai keterbatasan pengetahuan guru-guru terhadap model pembelajaran yang dapat mengoptimalkan aktivitas siswa, sehingga mereka hanya menggunakan pembelajaran secara konvensional. Dari hal ini bisa dikatakan 
bahwa salah satu faktor yang mengakibatkan kurangnya kemampuan siswa dalam matematika adalah cara mengajar yang dilakukan guru masih menggunakan pembelajaran konvensional, kurang melibatkan aktivitas mental siswa, guru memfokuskan pada latihan menyelesaikan soal-soal rutin dan drill. Ini menyebabkan ketidak aktifan siswa dalam memahami konsep ataupun nilai kehidupan social masyarakat. Hal ini yang menyebabkan hasil pendidikan sekolah kita hanya mampu menghasilkan insan-insan yang kurang memiliki kesadaran diri, kurang berpikir kritis, kurang kreatif, kurang mandiri, dan kurang mampu berkomunikasi secara luwes dengan lingkungan pembelajaran atau kehidupan sosial masyarakat. Oleh sebab itu suatu pendekatan pembelajaran yang tepat agar dapat mengubah proses pembelajaran dari situasi pendidik mengajar menjadi situasi peserta didik belajar sangat diperlukan. Inovasi yang diduga dapat mewujutkan proses belajar mengajar yang diharapkan adalah pembelajaran matematika dengan pendekatan problem posing.

Dari pengamatan, peneliti menemukan beberapa masalah yang terjadi di SMPN 48 Surabaya antara lain tentang keadaan peserta didik yang terjadi didalam kelas. Pada saat berlangsungnya proses belajar mengajar baik dengan mata pelajaran matematika maupun mata pelajaran lainnya masih banyak ditemukan peserta didik yang tidak serius mengikuti proses belajar mengajar. Peserta didik masih banyak yang tidak bisa tenang mengikuti pembelajaran ketika proses pembelajaran sedang berlangsung. Masih adanya yang keluar masuk walaupun guru mata pelajaran yang bersangkutan ada di dalam kelas. Peserta didik enggan bertanya karena merasa takut ketika bertanya peserta didik yang bersangkutan disuruh mengerjakan latihan yang ada dipapan tulis. Inti terpenting dalam disiplin matematika adalah Problem Posing. Sesuai pendapat Silver, E.A and Cai, J (1996) menyatakan bahwa inti terpenting dalam disiplin ilmu matematika dan hakikat berpikir matematis merupakan problem posing. Peserta didik akan mendapatkan pemahaman yang lebih baik jika memiliki beberapa pengalaman dala mengalami, mengenal dan membuat soal-soal mereka sendiri (NCTM, 1989). Dikarenakan inti dari aktivitas

matematika, termasuk aktivitas dimana siswa menyusun masalahnya sendiri dan menyelesaikannya terdapat pada problem posing. 


\section{B. Metode Penelitian}

Metode experiment adalah metode yang digunakan pada penelitian ini. Secara umum metode penelitian diartikan sebagai cara ilmiah untuk mendapatkan data dengan tujuan dan kegunaan tertentu. Dalam metode penelitian harus memperhatikan empat kata kunci yang dipakai yaitu, cara ilmiah, data, tujuan, dan kegunaan tertentu. Sugiyono (2017), mengemukakan bahwaa cara ilmiah untuk mendapatkan data yang valid dengan tujuan dapat ditemukan, dikembangkan, dan dibuktikan, suatu pengetahuan tertentu sehingga pada gilirannya dapat digunakan untuk memahami, memecahkan, dan mengantisipasi masalah dalam bidang pendidikan adalah pengertian dari metode penelitian pendidikan.

Penelitian diadakan di SMPN 48 Surabaya. Pendekatan kuantitatif adalah pendekatan penelitian yang digunakan. True fxperimental adalah desain penelitian eksperimen yang digunakan dalam penelitian ini, dalam bentuk Postest-only control design. Menurut Sugiyono (2017), ciri utama dari penelitian Postest-only control design adalah di pilih dengan purposive sampling. Kelas kontol diberikan perlakuan dengan model pembelajaran langsung dan kelas eksperimen diberikan perlakuan dengan model pembelajaran problem posing. Pada penelitian ini populasinya yaitu semua peserta didik kelas VIII SMPN 48 Surabaya dengan tahun ajaran 2019/2020, teknik purposive sampling adalah cara yang dilakukan dalam penentuan sampel. Memberikan posttest pada setiap kelas sampel adalah teknik pengumpulan data penelitian untuk mendapatkan hasil belajar matematika siswa.

Ada tiga (3) tahap dalam rancangan penelitian;

1. Tahap persiapan penelitian, dilakukan kegiatan antara lain : mempersiapkan surat ijin ke pihak Sekolah yang bersangkutan untuk peneliti akan melakukan penelitian demi memperlancar berjalannya penelitian tersebut. Mempersiapkan silabus, RPP, ppt, dan soal postest yang akan digunakan untuk diujikan kepada siswa. Selain itu peneliti mempersiapkan sebagian alat-alat tulis (ATK) yang diperlukan dalam proses penelitian. 
2. Tahap pelaksanaan penelitian dilaksanakan pembelajaran dengan menggunakan model pembelajaran langsung pada kelas kontrol dan model pembalajaran problem posing pada kelas experimen. Instrumen yang digunakan berupa postest dengan 5 butir soal uraian. Materi yang digunakan yaitu materi relasi dan fungsi.

3. Tahap akhir penelitian, dilakukan uji normalitas agar mengetahui bahwa data yang digunakan adalah data yang berdistribusi normal atau tidak, dan agar mengetahui bahwa data yang diambil dari kedua kelompok berasal dari populasi homogen atau tidak maka dilakukan uji homogenitas varians terlebih dahulu.

Setelah hasil statistik diperoleh baru dilakukan uji hipotesis penelitian, setelah itu peneliti menyimpulkan hasil akhir penelitian apakah ada atau tidak pengaruh model pembelajaran problem posing pada materi relasi dan fungsi terhadap hasil belajar matematika siswa kelas VIII SMP Negeri 48 Surabaya. Selanjutnya peneliti membuat laporan akhir hasil penelitian. Hipotesis secara statistik yang digunakan dirumuskan sebagai berikut:

$$
\text { H_o : } \boldsymbol{\mu} \mathbf{1}=\boldsymbol{\mu} \mathbf{2}
$$

Artinya bahwa hasil belajar matematika siswa antara kelas yang menggunakan model pembelajaran langsung dengan kelas yang menggunakan model pembelajaran problem posing Tidak ada perbedaan.

\section{H_1 $: \mu 1 \neq \mu 2$}

Artinya bahwa hasil belajar matematika siswa antara kelas yang menggunakan model pembelajara problem posing dengan model pembelajaran langsung, ada perbedaan (Sugiyono, 2017).

\section{Hasil Penelitian dan Pembahasan}

\section{HASIL PENELITIAN}

Penelitian ini dilakukan pada dua kelas sampel. Kelas kontrol dengan perlakuan model pembelajaran langsung dilakukan pada kelas VIII-I sedangkan untuk kelas experimen dengan perlakuan model pembelajaran problem posing dilakukan pada kelas VIII-J. Populasi pada penelitian ini adalah seluruh siswa kelas VIII SMPN 48 Surabaya. Pengambilan sampel dalam penelitian ini adalah 
dengan rekomendasi guru pamong berdasarkan proposal yang peneliti ajukan kepada guru pamong tersebut. Setelah guru pamong membaca proposal yang peneliti ajukan guru pamong tersebut menyetujui dan langsung menentukan sampel penelitian yang akan peneliti lakukan. Sampel tersebut adalah kelas VIII-J sebanyak 38 orang sebagai kelas eksperimen dan kelas VIII-I sebanyak 38 orang sebagai kelas kontrol. Penentuan kelas tersebut dipilih berdasarkan nilai raport siswa. Dimana nilai rata-rata raport kelas VIII-I lebih tinggi dibandingkan dengan nilai rata-rata raport kelas VIII-J yang ada pada guru pamong dan juga sepengetahuan guru pamong dengan pemahaman siswa tentang pembelajaran. Karena kebetulan kedua kelas tersebut adalah kelas yang diajarkan oleh guru pamong tersebut. Adapun materi yang digunakan oleh peneliti dalam penelitian ini adalah materi relasi dan fungsi.

Berdasarkan pengamatan yang dilakukan peneliti pada kelas eksperimen yaitu kelas VIII-J, siswa cukup antusias mengikuti pembelajaran matematika. Selain itu pada saat proses belajar mengajar siswa sangat antusias artinya peserta didik berebutan untuk maju mengerjakan contoh-contoh soal materi relasi dan fungsi yang diberikan oleh peneliti. Pada waktu peneliti memberikan latihan soal, peserta didik tidak enggan untuk bertanya jika ada pertanyaan soal yang tidak bisa dipecahkan oleh peserta didik. Tugas individu ataupun kelompok yang diberikan oleh pendidik untuk diselesaikan oleh peserta didik, peserta didik melaksanakannya penuh tertib. Akhir penelitian, disetiap kelas sampel peneliti memberikan posttest sebanyak lima soal uraian tujuannya adalah untuk mengetahui hasil belajar siswa. Ini. Setelah diperoleh soal yang valid, peneliti baru memberikan soal posttest tersebut kepada kedua kelas sampel. Hasil Soalsoal posttest dari kedua kelas sampel tersebut dapat dilihat pada tabel dibawah ini: 
Tabel 1. Daftar Nilai Postest Kelas eksperimen (VIII-J) SMPN 48 Surabaya

Mengurutkan data terendah ke tertinggi

\begin{tabular}{|c|c|c|c|c|c|c|}
\hline 81 & 81 & 81 & 82 & 83 & 84 & 84 \\
\hline 84 & 85 & 86 & 86 & 87 & 88 & 88 \\
\hline 90 & 90 & 90 & 90 & 91 & 92 & 92 \\
\hline 93 & 93 & 93 & 94 & 95 & 95 & 95 \\
\hline 95 & 96 & 98 & 98 & 98 & 98 & 98 \\
\hline 98 & 98 & 98 & \multicolumn{5}{|l}{} \\
\end{tabular}

Tabel 2. Daftar Nilai Postest Kelas kontrol (VIII-I) SMPN 48 Surabaya Mengurutkan data terendah ke tertinggi

\begin{tabular}{|c|c|c|c|c|c|c|}
\hline 81 & 81 & 81 & 81 & 81 & 81 & 81 \\
\hline 82 & 82 & 83 & 83 & 84 & 84 & 84 \\
\hline 84 & 85 & 85 & 85 & 85 & 85 & 86 \\
\hline 86 & 86 & 86 & 86 & 87 & 87 & 88 \\
\hline 89 & 90 & 90 & 90 & 92 & 92 & 93 \\
\hline 95 & 95 & 98 & & & & \\
\hline
\end{tabular}

\section{a. Uji Prasyarat Analisis}

1. Uji Normalitas

a) Uji normalitas nilai posttest kelas eksperimen dengan menggunakan uji Chi-Kuadrat $\left(x^{2}\right)$.

Berdasarkan perhitungan uji chi-kuadrat pada nilai Postest kelas eksperimen diperoleh nilai $\chi_{\text {hitung }}^{2}=10,25$ dan $\chi_{\text {tabel }}^{2}=11,070$. Karena $\chi_{\text {hitung }}^{2} \chi_{\text {tabel }}^{2}$ maka $\mathrm{H}_{\mathrm{o}}$ diterima. Dapat Memberikan kesimpulan karena $\chi_{\text {hitung }}^{2}<\chi_{\text {tabel }}^{2}$ maka $\mathrm{H}_{\mathrm{o}}$ diterima. Artinya, siswa kelas VIII-J dalam menyelesaikan soal postest matematika dapat dinyatakan berdistribusi normal.

b) Uji normalitas nilai posttest kelas kontrol dengan menggunakan uji Chi-Kuadrat $\left(x^{2}\right)$.

Berdasarkan perhitungan uji Chi-Kuadrat pada nilai Postest kelas kontrol diperoleh nilai $X_{\text {hitung }}^{2}=8,460$ dan $\chi_{\text {tabel }}^{2}=11,070$. Karena $\chi_{\text {hitung }}^{2}<\chi_{\text {tabel }}^{2}$ maka $\mathrm{H}_{\mathrm{o}}$ diterima. Dapat Memberikan kesimpulan. Karena $\chi_{\text {hitung }}^{2} \chi_{\text {tabel }}^{2}$ maka $\mathrm{H}_{\mathrm{o}}$ 
diterima. Artinya, siswa kelas VIII-I dalam menyelesaikan soal postest matematika dapat dinyatakan berdistribusi normal.

\section{Uji homogenitas (Uji-F)}

Data yang diperoleh sudah berdistribusi normal, tahap selanjutnya yaitu melakukan uji homogenitas terhadap nilai postest kelas VIII-J dan VIII-I

$\mathrm{H}_{\mathrm{o}}: \sigma_{\mathrm{a}}^{2}=\sigma_{\mathrm{g}}^{2}$ artinya kedua sampel yang di uji sama sama homogen.

$\mathrm{H}_{\mathrm{a}}: \sigma_{\mathrm{s}}^{2} \neq \sigma_{2}^{2}$ artinya kedua sampel yang di uji tidak homogen.

Kriteria Uji

$\mathrm{H}_{\mathrm{o}}$ : Diterima jika $F_{\text {hitung }} \leq F_{\text {tabel }}$

$\mathrm{H}_{\mathrm{o}}:$ Ditolak jika $F_{\text {hitung }} \geq F_{\text {tabel }}$

Berdasarkan perhitungan diperoleh nilai $F_{\text {hitung }}=1,66$ dan $F_{\text {tabel }}=1,73$ karena $F_{\text {hitung }} \leq F_{\text {tabel }}$ maka $\mathrm{H}_{\mathrm{o}}$ diterima. Dapat disimpulkan $\mathrm{H}_{\mathrm{o}}$ diterima. Artinya, kedua data tersebut homogen.

\section{Uji- $t$}

kelompok melalui game dan latihan pada media pembelajaran berbasis Android. Materi dan latihan pada media disajikan lebih menarik dengan tambahan gambar dan animasi sehingga dapat memotivasi siswa dalam melatih pemahaman konsep turunan fungsi aljabar. Sesuai dengan pendapat Novitasari bahwa multimedia interaktif dapat menyajikan konsep yang lebih menarik akibat gabungan dari gambar, animasi maupun suara yang menarik sehingga siswa lebih tertarik dalam memahami materi (Novitasari, 2016). Hal tersebut mendukung hasil penelitian Nurhairunnisah yang menyatakan bahwa, "Bahan ajar interaktif berbasis Android dinilai efektif untuk meningkatkan pemahaman konsep matematika siswa" (Nurhairunnisah. 2017).

Uji-t dilakukan upaya mengukur hipotesis ada tidaknya pengaruh model pembelajaran problem posing pada materi relasi dan fungsi terhadap hasil belajar matematika siswa kelas VIII SMP Negeri 48 Surabaya

a) Menetukan rumusan hipotesis

$\mathrm{H}_{\mathrm{o}}=\mu_{1}=\mu_{2}$

Artinya hasil belajar matematika siswa kelas VIII SMP Negeri 48 Surabaya pada materi relasi dan fungsi antara kelas yang menggunaka model 
pembelajaran problem posing dengan yang menggunakan model pembelajaran langsung tidak ada perbedaan

$\mathrm{H}_{\mathrm{o}}=\mu_{1} \neq \mu_{2}$

Artinya hasil belajar matematika siswa kelas VIII SMP Negeri 48 Surabaya pada materi relasi dan fungsi antara kelas yang menggunaka model pembelajaran problem posing dengan yang menggunakan model pembelajaran langsung ada perbedaan

Berdasarkan ketentuan uji-t diatas maka kriteria pengujian sebagai berikut: Kriteria pengujian hipotesis.

$H_{o}$ diterima jika: $-1,992 \leq t_{\text {hitung }} \leq 1,992$

$H_{o}$ ditolak jika: $t_{\text {hitung }}<-1,992$ atau $t_{\text {hitung }}>1,992$.

Dari analisis data diperoleh $t_{\text {hitung }}=2,7495$

b)

Penarikan Kesimpulan

Berdasarkan taraf signifikan 0,05 diperoleh $t_{\text {hitung }}>t_{\text {tabel }}$ yaitu 2,75 >1,992 maka $H_{o}$ doitolak dengan kata lain $H_{1}$ diterima yang berarti ada pengaruh model pembelajaran problem posing terhadap hasil belajar matematika siswa kelas VIII SMP.

\section{PEMBAHASAN}

Penelitian ini dilakukan di SMP Negeri 48 Surabaya tepatnya pada kelas VIII dengan materi relasi dan fungsi. Pada penelitian ini terdapat dua kelas yaitu kelas VIII-J (eksperimen) di ajar dengan menggunakan model pembelajaran problem posing dan kelas VIII-I (kontrol) di ajar dengan menggunakan model pembelajaran langsung. Pelaksanaan penelitian ini berlangsung 2 (dua) bulan baik dikelas control maupun dikelas experiment dengan sebanyak 8 (delapan) kali intensitas pertemuan. Model pembelajaran yang digunakan pada masingmasing kelas sampel berbeda namun materi yang digunakan sama. Untuk mengetahui hasil akhir yang dicapai oleh masing-masing kelas maka pada akhir penelitian peneliti memberikan soal posttest.

Berdasarkan hasil postest yang sudah dilakukan diketahui bahwa hasil nilai kedua kelas memiliki jumlah nilai yang berbeda dengan jumlah nilai rata-rata kelas experimen adalah 90,74 sedangkan jumlah nilai rata-rata kelas kontrol 
adalah 86,15. Berdasarkan hasil perhitungan dinyatakan bahwa jumlah nilai ratarata kelas experimen lebih tinggi dari jumlah nilai rata-rata kelas kontrol. Adapun faktor yang menjadi penyebab, diantaranya pada kelas eksperimen model pembelajarannya lebih dititik beratkan ke peserta didik karena peserta didik di haruskan membuat soal sendiri dan menyelesaikannya sendiri dari materi yang diterima dari guru. Dalam hal ini peserta didik dituntut untuk berpikir kritis. Sementara pada kelas kontrol model pembelajaran yang diterapkan lebih dititik beratkan kepada guru karena guru menyampaikan materi dalam bentuk ceramah. Dalam hal ini peserta didik tidak memiliki pengalaman untuk membuat permasalahan sendiri, pada akhirnya banyak peserta didik yang setelah pelejaran usai, ingatan peserta didik pada pembelajaran tersebut ikut usai.

Dalam kurikulum 2013 Pembelajaran matematika yaitu mengembangkan kemampuan siswa mulai dari pengamatan permasalahan konkret, kemudian ke semi konkret, dan akhirnya abtraksi permasalahan. Dalam hal ini diduga bahwa model pembelajaran problem posing dapat menjadi jawaban untuk meningkatkan nilai maupun prestasi peserta didik.

Problem Posing adalah suatu model pembelajaran dimana siswa diwajibkan membuat pertanyaan sendiri atau mengajukan soal yang terkait dengan materi yang dipelajari sebelumnya tanpa memanipulasi atau menjiplak soal pada buku pelajaran yang dipakai dan soal itu diselesaikan dengan sendiri oleh siswa tersebut, menurut Silver \& Cail dalam Sarbaini (Aris Shoimin, 2014 : 133).

Pada tahap mengajar di kelas kontrol peneliti merasakan suasana yang berbeda dari kelas eksperimen. Hal ini disebabkan cara belajar dan model pembelajaran yang diterapkan sudah berbeda. Proses belajar mengajar pada kelas kontrol pembelajaran lebih berpengaruh pada gur. Disaat mengawali pembelajaran, pertama pembelajaran dibuka dengan do'a, setelah itu menguraikan topik materi pelajaran yang nantinya akan dipelajari serta menjelaskan tujuan pembelajaran. Selanjutnya peneliti menyampaikan materi pembelajaran mulai dari konsep hingga ke contoh soal beserta penyelesaiannya. Terlihat sekali peserta didik hanya duduk diam dan bahkan kurang memperdulikan materi pelajaran yang disampaikan oleh peneliti didepan kelas. Disaat proses belajar mengajar sedang berlangsung peneliti mengajukan beberapa 
pertanyaan yang terkait dengan materi yang dipelajari. Peserta didik tidak menjawab apa yang ditanyakan oleh peneliti. Selanjutnya, dikarenakan siswa hanya diam dan mengangguk-mengangguk saja ketika di tanya, peneliti merasa jenuh dengan kondisi siswa yang pasif. Pada hal ini peneliti dapat menyadari bahwa peserta didik mulai jenuh dengan proses belajar mengajar yang dilakukan secara monoton. Oleh sebab itu peneliti memberikan latihan soal kepada peserta didik, untuk mengkur kemampuan peserta didik pada materi tersebut. Ketika peneliti memeriksa hasil kerja siswa ternyata masih sangat banyak jumlah siswa yang menyelesaikan tugasnya secara asal-asalan. Terlihat ketika di kelas siswa tidak aktif bertanya dengan peneliti dan teman-temannya. Suasana seperti ini penulis alami selama mengajar dikelas kontrol. Keseulitan yang sering penulis alami ketika dikelas kontrol diantaranya, suara gaduh dari siswa yang terkadang sulit dikendalikan, sikap pasif siswa dalam belajar, juga sikap kurang peduli dengan teman. Dengan melihat keadaan seperti ini sangat penting adanya suatu perubahan terhadap segi peranan seorang pendidik dalam melaksanakan proses belajar mengajar. Menjadi seorang pendidik seharusnya mampu memberikan inovasi yang baru dalam proses belajar mengajar supaya peserta didik tidak merasa jenuh dan kurang semangat untuk mengikuti pelajaran.

\section{Kesimpulan}

Dengan berdasarkan analisis data yang sudah dilakukan, pada pengujian hipotesis dengan menghasilkan $t_{\text {hitung }}$ sebesar 2,75 dan $t_{\text {tabel }}=t_{\left(74 ; \frac{0,05}{2}\right)}$ sebesar 1,992. Hal ini berarti $t_{\text {hitung }}>t_{\text {tabel }}$ dengan $2,75>1,992$ maka $H_{o}$ ditolak dengan kata lain $H_{1}$ diterima. Nilai rata-rata kelas eksperimen adalah $\bar{X}_{1}=90,74$ yang diberikan perlakuan dengan menggunakan model pembelajaran problem posing, tinggi dari nilai rata-rata kelas kontrol adalah $\bar{X}_{2}=86,16$ yang mengunakan perlakuan model pembelajaran langsung.

Oleh karena itu dapat disimpulkan bahwa ada pengaruh model pembelajaran Problem Posing terhadap hasil belajar matematika materi relasi dan fungsi siswa kelas VIII SMP Negeri 48 Surabaya. 


\section{Daftar Pustaka}

Nurhairunnisah. 2017. Pengembangan Bahan Ajar Interaktif untuk Meningkatkan Pemahaman Konsep Matematika pada Siswa SMA Kelas X. Tesis. Program S2 Universitas Negeri Yogyakarta. Yogyakarta.

Peraturan Menteri Pendidikan Dan Kebudayaan Republik Indonesia No. 58 tahun 2014 Tentang Kurikulum 2013 Sekolah Menengah Pertama/Madrasah Tsanawiyah.

Sari, R. U. 2014. Analisis Kemampuan Siswa dalam Memahami Materi Turunan Kelas XI IPS SMAN 1 Pariaman. Jurnal Pendidikan Matematika. 3(3). 22-

25 .

Setyadi, D. 2017. Pengembangan Mobile Learning Berbasis Android Sebagai Sarana Berlatih Mengerjakan Soal Matematika. Satya Widya. 33(2). 87-92.

Subramanya, S.R, dan Farahani, A. 2012. Design of a Smartphone App for Learning Concept in Mathematics and Engineering. International Journal of Innovation Science. 4(3). 173-183.

Erna Puji Astutik, S. M. (2016). Metode Statiska. Surabaya: Adi Buana University Press.

Miftahul Huda, M. (2013). Model-model Pengajaran dan Pembelajaran. Yogyakarta: Pustaka Belajar.

Prof. Dr. H. Karwono M.Pd \& Dr. Heni Mularsih, M. (2017). Belajar dan Pembelajaran Serta Pemanfaatan Sumber Belajar. Depok: PT. Raja Grafindo Persada.

Rosmala, I. \&. (2018). Model-model Pembelajaran Matematika. Jakarta: PT. BUMI AKSARA.

Shoimin, A.(2014). 68 Model Pembelajaran Inovatif Dalam Kurikulum 2013.Yogyakarta: AR-RUZZ MEDIA

Sugiyono, P. D. (2017). Metode Penelitian Pendidikan . Bandung: ALFABETA.

Thobroni, M. (2016). Belajar dan pembelajaran. Yogyakarta: AR-RUZZ MEDIA 